\title{
LEGAL NEEDS: CONCEPTS, SPECIFIC CLASSIFICATIONS
}

\section{ПРАВОВІ ПОТРЕБИ: ПОНЯТТЯ, СПЕЦИФІЧНІ КЛАСИФІКАЦЇ̈}

\section{Petro Rabinovych ${ }^{1}$ \\ Anna Nakonechna ${ }^{2}$}

DOI: https://doi.org/10.30525/978-9934-588-38-9-43

Abstract. There have been analyzed the concept and legal mechanism of satisfaction of legal needs, and also demonstrated their main classifications.

Such needs have been defined as the needs of people in high-quality legal regulation, as well as in legal assistance.

It has been highlighted the role (possibilities) of each of the main elements (means) of the mechanism of legal regulation in satisfaction of legal human needs , namely: 1) legal personality (legal competence and dispositive legal capacity). The need for legal personality is conditioned by the fact that neither natural nor legal person can exist and act without recognition of this property of the latter. Only it provides the opportunity to perform certain actions; 2) legal norm (placed either in normative legal acts, or in contracts, or in caselaw cases, etc.). The need for legal sources of law arises because they legally enshrine subjective rights and guarantee their realization; 3) subjective legal rights. The need for subjective legal rights is due to the fact that each person needs legal certainty of their actions, since it ensures their legitimacy and morality. They serve as a «key» provided by the state for carrying out activities of acquisition and consumption, use of certain vital goods - objects of legal relations; 4) legal facts as grounds for the emergence, change or termination of such rights. The need for legal facts is explained by the fact that they are the basis for the emergence, change or termination of legal relations, for the emergence of subjective rights of citizens in specific legal relationships. In addition, they are a kind of means of translating a person's legal personality into their subjective law, and they also form the necessary link in the transi-

\footnotetext{
${ }^{1}$ Doctor of Law, Professor of Department of Theory and Philosophy of Law, Ivan Franko National University of Lviv, Ukraine

${ }^{2}$ Assistant of Department of Theory and Philosophy of Law, Ivan Franko National University of Lviv, Ukraine

(C) Petro Rabinovych, Anna Nakonechna
} 
tion from state normative regulation of social relations to individual legal regulation; 5) legalism. The need for legitimacy is conditioned by the fact that it is a condition for the emergence and functioning of law and order, which is necessary for the ordering of social relations, and therefore the prevention of chaos and arbitrariness.

Quality as a characteristic of legal regulation is reflected by the following indicators: 1) the value; 2) economy; 3 ) effectiveness.

In addition, it has been determined that the need for legal assistance is conditioned by the need to ensure lawful, competent implementation of human rights and freedoms, their protection and restoration in case of violation.

\section{1. Вступ}

Мета і завдання дослідження полягають у виявленні специфіки правових потреб та здійсненні їх класифікації.

Методологічну основу дослідження становлять методи якісного аналізу та класифікації. Метод якісного аналізу дозволяє розглянути сутність поняття «правові потреби». Класифікацію застосовано до категорії «правові потреби» в цілому, елементів механізму правового регулювання як складової частини правової потреби.

Як і інші потреби, правові потреби є історичним утворенням та деякі 3 них виділялись ще Г. Гегелем у його класифікації потреб. Він їх називав потребами у праві та законі [1, с. 114-116]. Організація правового життя у багатьох аспектах залежить від них, а вони, у свою чергу, значною мірою зумовлюються попереднім і сьогоднішнім правовим розвитком.

Які ж із соціальних явищ належать саме до правових, - відповідь на таке питання, як вказує П.М. Рабінович, залежить від загального розуміння терміно-поняття «право». А воно, підкреслює науковець, ніколи не було і зараз не $є$, та, як видається, й у майбутньому не буде змістовно уніфікованим, односмисловим, неплюралістичним [2, с. 18].

Як відомо, найперший поділ загального праворозуміння полягає у тому, що у ньому розрізняють позитивістське (позитивне), 3 одного боку, та непозитивістське (непозитивне, або т. зв. «природне»), 3 іншого. Оскільки ж у нашому дослідженні з'ясовується вплив саме позитивно-правового регулювання на задоволення різноманітних потреб, то згадане терміно-поняття (і похідні від нього прикметники) використовуватимуться нами суто у позитивно-правовому значенні. 
Тому й інтерпретувати феномен правових потреб П. Рабінович спробував стосовно кожного 3 двох найбільш поширених різновидів позитивістського праворозуміння: соціологічного та легістського.

Так, 3 позицій соціологічно-позитивістського праворозуміння (зокрема, так званого соціально-природного), правова потреба визначається як потреба людини (чи групи людей) у наявності та використанні певних соціальних умов, можливостей і засобів для забезпечення здійснення іiі основоположних прав і свобод. Відтак, задоволення таких правових потреб слугує, на думку вченого, передумовою реалізації відповідних базових потреб їх носія (потреб матеріальних, соціальних, духовних тощо), адже не реалізувавши таку правову потребу, неможливо здійснити й відповідне «природне» людське право. Отож, 3 огляду на це, він відзначає, що правова потреба має інструментальне, так би мовити, «засобове» призначення.

3-поміж соціальних можливостей і засобів особливу роль, наголошує правознавець, відіграють явища державно-юридичні. Тому 3 позицій вже легістсько-позитивістського праворозуміння правовою потребою людини (чи групи людей) вважається потреба у наявності та використанні певних державно-юридичних засобів для забезпечення здійснення іiі прав і свобод. Такі засоби, кожен з яких може бути предметом відповідних правових потреб, аналізуватимуться нижче.

Задоволення саме таких - легістсько-позитивістських - людських потреб, стверджує вчений, теж слугує однією з необхідних передумов наступного задоволення базових, неюридичних за змістом, потреб їхніх носіїв. Отож у зазначеному сенсі правові потреби - це, іншими словами, потреби в державно-юридичних гарантіях (засобах, важелях, інструментах) здійснення прав і свобод людей чи їхніх груп. При чому, П.М. Рабінович акцентує на гарантіях саме ефективних, про які йдеться у Конвенції про захист прав людини і основоположних свобод (ст. 13) [2, с. 19-21].

\section{2. Загальне поняття правових потреб}

Виходячи із усього сказаного вище та опираючись на легістсько-позитивістське праворозуміння, можемо запропонувати таку дефініцію аналізованого поняття: правові потреби - ие потреби людей $y$ якісному й ефективному позитивно-правовому регулюванні, а також потреби в юридичній допомозі. 
У науковій та навчальній літературі правовим регулюванням вважають діяльність компетентних суб'єктів, яка здійснюється за допомогою певних юридичних засобів. Їх сукупність становить механізм, що включає: юридичну правосуб'єктність (правоздатність та дієздатність); юридичні норми (вміщені чи у нормативно-правових актах, чи у договорах, чи у судово-прецедентних рішеннях тощо); правовідносини; суб'єктивні юридичні права; юридичні обов'язки; юридичні факти як підстави виникнення, зміни чи припинення таких прав (зокрема такі юридичні факти, як ухвалення актів офіційного правотлумачення - правоконстатуючих або правовідновлювальних, або правозмінних, або ж правоприпиняючих індивідуальних юридичних актів); правопорядок, законність. Отож, стисло охарактеризуємо роль (можливості) кожного з основних елементів (засобів) механізму правового регулювання у задоволенні правових потреб людини.

Потреба у правосуб'єктності зумовлена тим, що ні фізична, ні юридична особа не можуть існувати й діяти без визнання цієї властивості останніх. Виключно вона надає можливість вчиняти ті чи інші дії.

Потреба у суб'єктивних юридичних правах спричинена тим, що кожна людина потребує правової визначеності своїх дій, оскільки це забезпечує їх правомірність та моральність. Вони слугують свого роду «ключем», наданим державою для здійснення діяльності із здобуття та споживання, використання певних життєво необхідних благ - об'єктів правовідносин.

Потреба в юридичних нормах та у нормативно-правових актах виникає внаслідок того, що вони юридично закріплюють суб'єктивні права та гарантують їх реалізацію.

Потреба в юридичних фактах пояснюється тим, що саме вони $є$ підставою для виникнення, зміни чи припинення правовідносин, для виникнення суб'єктивних прав громадян у конкретних правовідносинах. Окрім цього, вони є своєрідним засобом трансформування правосуб'єктності особи у її суб' єктивне право, а також становлять необхідну ланку у переході від державного нормативного регулювання суспільних відносин до індивідуального правового регулювання.

Потреба у законності викликана тим, що вона є умовою виникнення та функціонування правопорядку, який необхідний для впорядкованості суспільних відносин, а відтак попередження хаосу та свавілля. 
Така характеристика правового регулювання, як його якість, відображається насамперед такими показниками:

- цінність юридичного регулювання. Вона полягає в його позитивній значимості для задоволення потреб існування і розвитку людини, соціальних спільнот, об'єднань, усього суспільства;

- економність юридичного регулювання. Характеризується обсягом соціальних витрат, потрібних для досягнення його мети;

- ефективність юридичного регулювання. Визначається співвідношенням реальних результатів здійснення цього регулювання 3 його метою [3, с. 202].

Потреба у правовій допомозі зумовлюється необхідністю забезпечення правомірної, компетентної, дійсної реалізації прав і свобод людини, їх захисту та відновлення у разі порушення.

\section{3. Специфічні класифікації правових потреб}

Загальна класифікація людських потреб в основному може бути поширена і на потреби правові. Зокрема, можна розмежувати правові потреби за такими критеріями, як: суб'єкт (носій); сфери людської діяльності; тривалість; рівень (ступінь) задоволення. Крім того, правові потреби можна класифікувати і за іншими, специфічними для них, критеріями.

Виділяють такі різновиди правових потреб:

- За кількісним складом їх носії:

1) індивідуальні (наприклад, потреба особи звернутися до суду 3 позовом про відшкодування шкоди, завданої знищенням іії майна);

2) колективні (потреби групи осіб у створенні громадського об'єднання, у проведенні мирного зібрання тощо);

3) «змішані» (зокрема, потреби у скеруванні звернень до органу державної влади чи місцевого самоврядування можуть бути як індивідуальними, так і колективними).

- За сферами життедіяльності людини:

1) вітальні (наприклад, потреба у безпеці (безпекова потреба) і т. п.);

2) особистісні (потреби у державній реєстрації прізвища, імені та по батькові, у державних гарантіях свободи віросповідання тощо);

3) економічні (потреби у державних гарантіях захисту права власності, здійснення підприємницької діяльності, працевлаштування); 
4) політичні (потреби в отриманні громадянства та гарантуванні державою неможливості вислання за іiі межі, у створенні державою ефективних механізмів реалізації прав і свобод та ін.);

5) у сфері соціального захисту (потреби у створенні більш чітких положень стосовно права на захист материнства та дитинства, у розширенні системи соціального забезпечення);

6) культурно-духовні (для прикладу, потреби у державних гарантіях свободи літературної, художньої, наукової та технічної творчості, збереження історичних пам'яток та інших об'єктів, що становлять культурну цінність, у вжитті державою заходів для повернення культурних цінностей, які знаходяться за іï межами, в організації державою музейного фонду та у наданні доступу до ознайомлення 3 його надбаннями).

- За часом існування:

1) постійні (зокрема, потреби у нормативно-правовому врегулюванні суспільних відносин за посередництвом держави);

2) тимчасові (наприклад, потреби в отриманні різних видів правової допомоги).

- За рівнем (ступенем) задоволення:

1) повно, здебільшого, неповно, частково чи взагалі не задоволені;

2) якісно чи неякісно задоволені;

3) своєчасно чи невчасно задоволені.

- За юридично-галузевою ознакою:

1) конституційні (наприклад, потреби брати участь в управлінні державними справами, бути обраним до органів влади, у визнанні певних актів такими, що не відповідають конституції держави);

2) цивільні (потреби у вступі в договірні відносини певного виду, в отриманні відшкодування моральної шкоди тощо);

3) сімейні (зокрема, потреби в усиновленні дітей, в отриманні аліментів на утримання дітей або батьків);

4) адміністративні (потреби в отриманні реєстраційних, довідкових й інших адміністративних послуг та ін.);

5) кримінальні (для прикладу, потреби у притягненні до кримінальної відповідальності та у призначенні покарання за вчинені злочини);

6) фінансові (потреби у сплаті податків, зокрема на утримання органів влади, що забезпечують громадський порядок і безпеку тощо); 
7) кримінально-процесуальні (потреби у проведенні досудового розслідування за кожним фактом виявлення ознак злочину, у справедливому судовому розгляді кримінальних справ);

8) цивільно-процесуальні (потреби у визнанні судом особи недієздатною чи обмежено дієздатною, у встановленні фактів, що мають юридичне значення, у справедливому судовому розгляді цивільних справ та ін.);

9) інші.

Так, російський дослідник М. О. Барінов визначає такі характерні риси майнових потреб, які задовольняються насамперед цивільно-правовим регулюванням:

- завжди необхідність в чому-небудь;

- вони проявляються завше як об'єктивна необхідність;

- вони є чинником формування правової системи держави, що включає в себе такі аспекти, як: конструкція майнових потреб дозволяє подивитись на проблему задоволення потреб громадян в більш широкому плані, а не лише через призму майнових відносин, що виступають предметом цивільного права; право громадян і їх об'єднань на майнові потреби розглядається як нова функція держави, яка полягає в тому, що ця ідея виражається як принцип цивільного права.

Задоволення таких потреб потребує юридичного забезпечення правовими засобами, що визначаються як юридичні можливості, закладені в нормах права і його окремих інститутах, які застосовуються в процесі їх реалізації з метою задоволення майнових потреб. Такими правовими засобами є норми права, його окремі інститути, правосуб'єктність, реалізація і захист прав, інститути представництва, позовної давності, право власності, договори, послуги і т. ін. [4, с. 98].

- За юридичним статусом індивідуального носія:

1) правові потреби громадян (потреби обирати представників до органів державної влади (главу держави, членів парламенту), у вирішенні на референдумі питань загальнодержавного значення тощо), іноземців (наприклад, потреби в отриманні візи на в’їзд до іншої держави, у провадженні підприємницької діяльності за межами власної держави), осіб без громадянства (потреба в отриманні посвідки про тимчасове чи постійне місце проживання, в отриманні статусу біженця та ін.); 
2) людей з інвалідністю (наприклад, потреби у державних гарантіях інклюзивної освіти, облаштування входів до будівель пандусами, створення автомобілів, пристосованих для людей з проблемами опорно-рухового апарату);

3) дітей (потреби у державних гарантіях утримання та виховання батьками до настання повноліття, виконання судових рішень про стягнення аліментів на утримання дітей тощо);

4) військовослужбовців (потреби у державних гарантіях реабілітації після участі у воєнних діях, надання належного грошового та речового забезпечення та ін.);

5) правові потреби представників інших соціальних груп (студентів, пенсіонерів, суддів тощо).

- За суб 'єктом задоволення правових потреб - правові потреби, що задовольняються:

1) органами державної влади (для прикладу, потреба людини у державній реєстрації як безробітного у разі неможливості працевлаштування, потреби внутрішньо переміщених осіб у державних гарантіях забезпечення єдності родини, сприяння у поверненні на попереднє місце проживання);

2) органами місцевого самоврядування (потреби у приватизації комунальної земельної ділянки для ведення господарської діяльності, в триманні дозвільних документів для проведення реконструкції приватного житлового будинку тощо);

3) іншими компетентними суб'єктами (юридичними особами, громадськими об'єднаннями і т. д.) (зокрема, потреби в отриманні кваліфікованої правової допомоги, освіти відповідного рівня, житлово-комунальних послуг належної якості);

4) фізичними особами (потреба у наданні освіти дитині та ін.).

- Залежно від безпосередньої участі суб'єкта-носія циих потреб у їх задоволенні:

1) активні - передбачають безпосередню участь носія в їх задоволенні (наприклад, потреби у скеруванні звернень до органів державної влади та місцевого самоврядування);

2) пасивні - не передбачають безпосередню участь носія в їх задоволенні (потреби у нормативно-правовому врегулюванні суспільних відносин за посередництвом держави, у створенні державою ефективних механізмів реалізації прав і свобод тощо). 
Потреби в якісному й ефективному правовому регулюванні та в юридичній допомозі як різновиди правових потреб можуть бути конкретизовані та диференційовані ще й за додатковими критеріями.

- Потреба у визнанні юридичної правосуб'єктності включає:

1) потребу у визнанні правоздатності (здатності мати права та обов'язки), яка у свою чергу поділяється на:

а) потребу у загальній правоздатності, яка полягає у тому, що лише завдяки їй будь-яка особа чи організація може бути суб'єктом права як такого;

б) потребу у галузевій правоздатності, яка зумовлена необхідністю особи чи організації бути суб'єктом тієї чи іншої галузі права;

в) потребу у спеціальній правоздатності, яка пов'язана із бажанням володіти особливими знаннями, уміннями, навичками, які повинен мати суб'єкт права. Наприклад, надавати медичні або юридичні послуги може лише особа, яка має відповідну професію і ліцензію на цей вид діяльності [5, с. 363];

2) потребу у визнанні дієздатності (здатності людини здійснювати ті чи інші юридичні дії, спрямовані на виникнення, зміну чи припинення прав та обов'язків), яка у свою чергу (відповідно до розмежування дієздатності за обсягом у чинному законодавстві на повну, неповну, часткову і обмежену) поділяється на:

а) потребу у повній дієздатності, яка спричинена тим, що суб'єкт права може відчувати себе повноцінним лише за умови наділеності усім спектром суб'єктивних прав;

б) потребу у неповній та частковій дієздатності, яка зумовлюється формуванням у дитини (малолітньої та неповнолітньої) самостійності. Вона їй необхідна для здійснення «перших кроків у доросле життя». Для прикладу, неповна дієздатність надає неповнолітній особі право самостійно розпоряджатися своїм заробітком, бути учасником юридичних осіб, самостійно укладати договір банківського вкладу тощо (ст. 32 ЦКУ), а часткова надає малолітній особі право здійснювати дрібні побутові правочини, що задовольняють іiі побутові потреби, а також особисті немайнові права на результати інтелектуальної, творчої діяльності (ст. 31 ЦКУ);

в) потребу в обмеженій дієздатності особи, що викликана ії психічними розладами, зловживанням спиртними напоями, наркотичними засобами, токсичними речовинами, азартними іграми тощо. 
- Потреба у юридичних нормах за значущістю нормативно-правових актів поділяється на:

1) потребу у нормах законів. У цивільному, земельному та інших кодексах є безліч положень, які необхідно було б конкретизувати, створюючи спеціальні закони, зокрема слід розробити проекти законів, наприклад про державний земельний (іпотечний) банк;

2) потребу у нормах підзаконних нормативно-правових актів. В окремих галузях права, зокрема у галузі трудового права, зберігають свою дію підзаконні нормативно-правові акти ще Радянського Союзу (напр., Указ Президії Верховної Ради СРСР «Про умови праці робітників і службовців, зайнятих на сезонних роботах» від 24.09.1974 p. № 310-IX, Постанова Ради Міністрів СРСР «Про порядок та умови суміщення професій (посад)» від 04.12.1981 р. № 1145), що викликає необхідність їх скасування і прийняття сучасних, удосконалених підзаконних нормативно-правових актів України;

3) потребу у нормативно-правових договорах, яка зумовлена швидкістю, зручністю та простотою такого способу регулювання суспільних відносин, а також врахуванням взаємних інтересів суб'єктів;

4) потребу у нормативно-правових прецедентах, котра у романо-германській правовій системі спричинена необхідністю тлумачення норм права, які $є$ неоднозначними або містять оціночні поняття, а в англо-саксонській - необхідністю створення нових норм задля заповнення прогалин.

- Потреба у суб'єктивних юридичних правах поділяється:

А) За характером людських потреб, які цими правами забезпечуються:

1) потреба у вітальних правах (потреба у праві на житло, праві на фізичну недоторканність тощо);

2) потреба в особистісних правах (потреба у праві на честь і гідність, праві на свободу світогляду і віросповідання, праві на свободу совісті та ін.);

3) потреба в економічних правах (потреба у праві на працю, праві на власність, праві на вибір професії, роду занять тощо);

4) потреба в політичних правах (потреба у праві на свободу думки та слова, праві на інформацію, праві на проведення мітингів і т. і.);

5) потреба в соціальних правах (потреба у праві на отримання зарплати, праві на страйк, праві на відпочинок і т. д.); 
6) потреба в культурно-духовних правах (потреба у праві на освіту, праві на охорону інтелектуальної власності, праві на участь у культурному житті тощо).

Б) За суб’єктним складом здійснення:

1) потреба в індивідуальних правах (потреба у праві на свободу вираження поглядів, на виховання своєї дитини та ін.);

2) потреба в колективних правах (потреба у праві на утворення громадських об'єднань, проведення демонстрацій тощо);

3) потреба у «змішаних» правах (здійснюються як індивідуальними, так і колективними діями).

В) За суб'єктами-носіями прав:

1) потреба громадян у правах (потреба у праві на свободу об'єднання у політичні партії, праві брати участь в управлінні державними справами тощо), іноземців (потреба у праві на трудову діяльність за межами держави громадянства та ін.), осіб без громадянства (потреба у праві на участь в об'єднанні громадян держави перебування і т. ін.);

2) людей з інвалідністю (потреба у праві на отримання посвідчення, що підтверджує статус інваліда тощо);

3) дітей (потреба у праві на піклування і турботу, достатне харчування та ін.);

4) військовослужбовців (наприклад, потреба у праві на зарахування часу перебування на військовій службі до страхового стажу, стажу роботи, стажу роботи за спеціальністю, а також до стажу державної служби);

5) потреба представників інших соціальних груп у правах (студентів, пенсіонерів, суддів тощо).

Г) За їх значенням для суб'єкта:

1) потреба в основних правах (життєво необхідних). Наприклад, потреба у праві на охорону здоров’я і т. п.

2) потреба у допоміжних правах. Зокрема, потреба у свободі вибору професії тощо.

Г) За способом їх здійснення:

1) потреба в активних правах (потреба у вчиненні активних дій);

2) потреба у пасивних правах (потреба у свободі від втручання, від перешкоджання з боку інших суб'єктів).

- Потреба в юридичних фактах охоплює: 
1) потребу в ухваленні правоконстатуючих актів (потреба у свідоцтві про шлюб, у свідоцтві про смерть);

2) потребу в ухваленні правовідновлювальних актів (потреба в наказі про відновлення на посаді);

3) потребу в ухваленні правозмінних актів (потреба в акті про заміну арешту підслідного на підписку про невиїзд);

4) потребу в ухваленні правоприпиняючих актів (потреба у протесті прокурора з приводу незаконного виселення громадянина).

- Потреба у законності складається з:

1) Потреби у іiі загальності, зумовленої тим, щоб ніхто із суб'єктів права самостійно не визначав обсяг вимог закону, який поширюється особисто на них, не нехтував цими вимогами, а також не ставив себе вище закону.

2) Потреби їі єдності - задля забезпечення однакового сприйняття i виконання вимог законів.

3) Потреби у її забезпеченості дієвими гарантіями (загальносоціальними та юридичними).

До загальносоціальних гарантій законності належать:

1) економічні - стан економічного розвитку суспільства, ритмічність роботи господарського механізму країни, підвищення продуктивності праці і зростання обсягу виробництва; різноманіття і рівність усіх форм власності, рівність економічних можливостей суб'єктів суспільних відносин. Наявність економічної незалежності суб'єктів права створює об'єктивні умови для їх зацікавленості у законності;

2) політичні - рівень демократизму конституційного ладу, тобто розвиненості системи народовладдя, демократичних форм та інститутів його здійснення; політичного плюралізму, який дає змогу особі вільно самовизначатися, об'єднуватися в організації за різними інтересами; додержання принципу поділу влади;

3) соціальні - життєвий рівень населення, необхідна забезпеченість громадян найважливішими житлово-комунальними, соціально-культурними та іншими послугами; надання державної соціальної допомоги незаможним сім'ям або самотнім громадянам (субсидій, компенсацій, життєво необхідних товарів); соціальне страхування, ефективна соціальна служба; відсутність безробіття або низький його рівень; 
4) ідеологічні (духовні) - ступінь розвиненості правосвідомості, комплекс моральних і правових уявлень про необхідність законослухняної поведінки, недопустимість вчинення аморальних проступків, які водночас є протиправними; ідеологічний плюралізм, не нав'язування державою ідеології, а турбота про правову освіту, виховання, правову культуру; недопущення культивування насильства, націоналізму, расової ворожнечі, цинізму, байдужості до соціальних цінностей, зокрема й до права. Істотне значення має широка поінформованість населення, свобода преси, думок, що дає змогу вести публічну боротьбу з правопорушеннями у будь-якій сфері державного і суспільного життя.

До юридичних гарантій законності належать:

1) юридичні умови - якісний стан чинних джерел (форм) права: нормативно-правових актів, нормативно-правових договорів, судових прецедентів, правових звичаїв тощо, а також актів тлумачення норм права і правозастосовчих актів;

2) правові способи - досконале законодавство і його відповідність нормам конституції; нагляд і контроль за станом законності, включаючи конституційний судовий контроль; попередження і припинення правопорушень; захист, відновлення порушених прав; реалізація юридичної відповідальності; наявність надійних і загальнодоступних юридичних процедур і процесів; розвинена правосвідомість і правова культура населення тощо;

3) організаційно-правові засоби - реалізація принципу поділу влади; ретельний підбір кадрів; організація умов для нормального функціонування юрисдикційних та правоохоронних органів, їх структурних підрозділів з метою ефективної протидії випадкам організованої злочинності, наркобізнесу, тероризму, корупції і т. д.

4) Потреби у верховенстві Конституції та закону, яка спричинена необхідністю строгої підпорядкованості Конституції, загальновизнаним принципам і нормам міжнародного права, закону, всім нормативним актам і всім актам правореалізації для підтримання правопорядку [6].

5) Потреби у рівності усіх громадян у правовому захисті та у виконанні ними правових приписів, породженої тим, що цей принцип $\epsilon$ важливою умовою існування правової держави. Окрім цього, він $\epsilon$ логічним продовженням принципу справедливості. 
6) Потреби у якісному та ефективному застосуванні норм права. Законність потребує ефективної правозастосовчої діяльності, що передбачає недопущення бюрократизму, байдужості до інтересів людей, своєчасну реакцію на будь-які заяви громадян щодо обмеження їх прав і свобод. Якісним можна вважати таке застосування права, у процесі якого дотримані усі його вимоги, принципи і стадії.

7) Потреби у механізмі соціально-юридичного забезпечення прав людини.

До основних його підсистем належать:

a) механізм реалізації прав людини, який містить заходи, що спроможні створити умови для реалізації прав і свобод людини (юридичний, психологічний, соціальний).

Юридичний механізм характеризують як систему юридичних норм, фактів, документів та основних форм і способів організації їх здійснення.

Психологічний механізм - це цінності, орієнтації, установки, цілі, інтереси і потреби, мотивація, вольова активність людини у процесі здійснення прав і обов'язків.

Соціальний механізм включає в себе політичні, організаційні, ідеологічні та інші чинники [7, с. 219];

б) механізм охорони прав людини, що охоплює міри профілактики правопорушень для утвердження правомірної поведінки особи (наприклад, для неповнолітніх застосовуються такі напрями профілактики, як: 1) надання правових знань педагогами під час викладання певних предметів, 2) проведення вікторин, тематичних уроків, 3) зустрічі 3 працівниками правоохоронних органів, які можуть відбуватися за місцем навчання дітей або за місцем роботи правоохоронців (екскурсії до відділів міліції, постів ДАІ, організацій) та ін.);

в) механізм захисту прав людини, який включає безліч його способів (ст. 16, 387 (право власника на витребування майна із чужого незаконного володіння) ЦКУ тощо) [8, с. 190].

8) Потреби у доцільності, тобто: 1) відповідності закону та інших джерел об'єктивного юридичного права цілям забезпечення основоположних прав людини та інших суб' єктів, 2) необхідності вибору в межах закону найбільш ефективного (оптимального) засобу досягнення мети закону. Завдяки їй забезпечення основоположних прав людини та інших суб'єктів може бути результативним. 
9) Потреби у гарантованості основних прав і свобод людини, яка виникає задля забезпечення пріоритету прав індивіда, а також гарантій їх з боку держави.

10) Потреби у взаємозв'язку законності і демократії, яка зумовлена тим, що законність $є$ основою для становлення і розвитку демократії, і навпаки, демократія є основним чинником зміцнення режиму законності. Без демократії законність може перерости у свавілля держави щодо індивіда, без законності демократія може виродитись в охлократію (влада натовпу), анархію і свавілля натовпу щодо індивіда.

11) Потреби у невідворотності юридичної відповідальності, що викликана необхідністю своєчасного розкриття протиправних діянь та призначення справедливого покарання [5, с. 537-538].

- Потреба у правопорядку охоплює:

1) потребу у світовому правопорядку, яка зумовлена наявністю глобальних проблем, вирішення яких можливе тільки при згоді і співпраці різних держав. Право, його загальнолюдські сутнісні якості забезпечують можливість його становлення і розвитку. Властивості права дозволяють взаємодіяти нормам внутрішньодержавного і міжнародного права у справі формування світового правопорядку.

Реальний характер світового порядку забезпечується наявністю i функціонуванням мережі міжнародних організацій планетарного і регіонального масштабу, а саме: ООН, Міжнародною організацією праці, Всесвітньою організацією охорони здоров'я, Всесвітньою організацією інтелектуальної власності, Міжнародною організацією цивільної авіації тощо [5, с. 541];

2) потребу в інтеграційному правопорядку (Свропейський Союз), породжену пріоритетом прав людини, порівняно 3 іншими політичними і правовими цінностями, реалізація яких є відображенням і втіленням панування права, верховенства та ефективності закону, плюралізму й демократії;

3) потребу у національному правопорядку, що спричинена необхідністю захисту та гарантування прав людини і громадянина національним законодавством та судовою системою [9, с. 40].

У контексті надання правової допомоги виділяють такі юридичні послуги:

- безоплатні, які поділяються на: 
а) первинні:

1) надання правової інформації;

2) надання консультацій і роз'яснень $з$ правових питань;

3) складення заяв, скарг та інших документів правового характеру (крім документів процесуального характеру);

4) надання допомоги в забезпеченні доступу особи до вторинної правової допомоги та медіації (ч. 2 ст. 7 ЗУ «Про безоплатну правову допомогу»);

б) вторинні:

1) захист від обвинувачення;

2) здійснення представництва інтересів осіб, що мають право на безоплатну вторинну правову допомогу, в судах, інших державних органах, органах місцевого самоврядування, перед іншими особами;

3) складення документів процесуального характеру;

- оплатні (надаються адвокатами, адвокатськими об'єднаннями, об’єднаннями громадян та суб'єктами підприємницької діяльності) (ч. 2 ст. 13 ЗУ «Про безоплатну правову допомогу»).

Порядок надання юридичних послуг регулюється Конституцією, яка закріплює право громадян на правову допомогу, Законом України «Про адвокатуру та адвокатську діяльність» та Законом України «Про безоплатну правову допомогу».

ЗУ «Про адвокатуру та адвокатську діяльність» від 05.07.2012 p. № 5076-VI [10, с. 282] визначає вимоги, що пред’являються до адвоката, а саме: особливий порядок набуття статусу адвоката, складання кваліфікаційного іспиту, реєстрація статусу, можливість позбавлення статусу адвоката у разі невиконання або неналежного виконання адвокатом своїх професійних обов'язків тощо. Таких вимог законодавець не ставить до жодного іншого суб'єкта, що має право надання правової допомоги, а також юридичних послуг, які можуть надаватися і юридичними особами.

Віднесення саме до компетенції адвокатури діяльності із забезпечення права на захист від обвинувачення і надання правової допомоги у визначених Конституцією випадках є важливою, забезпеченою державою гарантією належного рівня професійного захисту, консультування та іншої юридичної допомоги, оскільки лише адвокати наділені спеціальними професійними правами, гарантіями адвокатської діяль- 
ності, лише щодо них встановлені певні професійні обов'язки, передбачена адвокатська таємниця, правила адвокатської етики та відповідальність за неналежне здійснення адвокатом його обов'язків.

ЗУ «Про безоплатну правову допомогу» від 02.06.2011 р. № 3460-VI, в редакції від 02.10.2018 р. № 2581-VIII [11, с. 577] передбачає форми та порядок іiї надання.

У розділі другому визначається порядок надання первинної правової допомоги. Безоплатна первинна правова допомога - вид державної гарантії, що полягає в інформуванні особи про іiї права і свободи, порядок їх реалізації, відновлення у разі їх порушення та порядок оскарження рішень, дій чи бездіяльності органів державної влади, органів місцевого самоврядування, посадових і службових осіб (ст. 7).

Суб'єктами права на безоплатну первинну правову допомогу визнаються усі особи, які перебувають під юрисдикцією України (ст. 8). Суб’єктами надання безоплатної первинної правової допомоги є:

1) органи виконавчої влади;

2) органи місцевого самоврядування;

3) фізичні та юридичні особи приватного права;

4) спеціалізовані установи;

5) центри з надання безоплатної вторинної правової допомоги (ст. 9).

Стаття 10 встановлює порядок розгляду звернень про надання безоплатної первинної правової допомоги, відповідно до якого звернення про іiі надання надсилаються або подаються особами, які досягли повноліття, безпосередньо до центральних та місцевих органів виконавчої влади, територіальних органів центральних органів виконавчої влади та органів місцевого самоврядування відповідно до їх компетенції. Звернення, що стосуються дітей, надсилаються або подаються їх законними представниками, а ті, що стосуються осіб, визнаних судом недієздатними, або дієздатність яких обмежена судом, - їх опікунами чи піклувальниками.

Органи виконавчої влади та органи місцевого самоврядування у разі письмового звернення осіб з питань, що віднесені до їх повноважень, зобов'язані надати такі послуги упродовж 30 календарних днів 3 дня надходження звернення. Якщо у зверненні особи міститься лише прохання про надання відповідної правової інформації, така правова допомога надається не пізніше 15-денного терміну 3 дня отримання 
звернення. Вказаним органам забороняється встановлювати плату за надання будь-якого з видів правових послуг та за видачу особам бланків заяв, звернень, запитів, довідок, інших документів, подання яких передбачено законодавством для реалізації прав і свобод людини і громадянина.

Якщо питання, порушені у зверненні, не належать до компетенції зазначених органів, то орган упродовж 5 календарних днів повинен надіслати це звернення до відповідного органу та повідомити про це особу, яка подала звернення.

Окрім цього, якщо під час розгляду звернення про первинну допомогу встановлено, що особа потребує надання вторинної правової допомоги, орган виконавчої влади чи орган місцевого самоврядування, який розглядає звернення, зобов'язаний роз'яснити особі або iii законному представнику порядок подання звернення про надання безоплатної вторинної правової допомоги.

Організація особистого прийому осіб для надання безоплатної первинної правової допомоги відбувається таким чином, що він проводиться постійно в установлені дні та години, і його графік повинен бути доведений до відома осіб. Проведення особистого прийому має забезпечуватись висококваліфікованими працівниками, які можуть чітко i доступно надати роз'яснення положень законодавства та консультації 3 питань реалізації прав і свобод людини і громадянина та виконання обов'язків. Якщо під час особистого прийому встановлено, що особа потребує надання безоплатної вторинної правової допомоги, працівник, який проводить особистий прийом, зобов'язаний роз'яснити їй порядок подання звернення про надання такої допомоги (ст. 11).

Розділ 3 визначає порядок надання вторинної правової допомоги. Безоплатна вторинна правова допомога - вид державної гарантії, що полягає у створенні рівних можливостей для доступу осіб до правосуддя. Вона включає такі види правових послуг: 1) захист; 2) здійснення представництва інтересів осіб, що мають право на безоплатну вторинну правову допомогу, в судах, інших державних органах, органах місцевого самоврядування, перед іншими особами; 3) складення документів процесуального характеру (ст. 13).

Суб’ єктами права на безоплатну вторинну правову допомогу визнаються: 
1) особи, які перебувають під юрисдикцією України, якщо їхній середньомісячний дохід не перевищує двох розмірів прожиткового мінімуму, розрахованого та затвердженого відповідно до закону для осіб, які належать до основних соціальних і демографічних груп населення, а також особи з інвалідністю, які отримують пенсію або допомогу, що призначається замість пенсії, у розмірі, що не перевищує двох прожиткових мінімумів для непрацездатних осіб - на всі види правових послуг, зазначених вище у ст. 13;

2) діти, у т. ч. діти-сироти, діти, позбавлені батьківського піклування, діти, які перебувають у складних життєвих обставинах, діти, які постраждали внаслідок воєнних дій чи збройного конфлікту, - на всі види правових послуг, зазначених вище;

21) внутрішньо переміщені особи - на всі види правових послуг, зазначених вище;

22) громадяни України, які звернулися із заявою про взяття їх на облік як внутрішньо переміщених осіб, - на правові послуги, передбачені пп. 2 i 3 ст. 13, з питань, пов'язаних з отриманням довідки про взяття на облік внутрішньо переміщеної особи, до моменту отримання такої довідки;

3) особи, до яких застосовано адміністративне затримання, - на правові послуги, передбачені пп. 2 і 3 ст. 13;

4) особи, до яких застосовано адміністративний арешт, - на правові послуги, передбачені пп. 2 і 3 ст. 13;

5) особи, які відповідно до положень кримінального процесуального законодавства вважаються затриманими, - на правові послуги, передбачені пп. 1 і 3 ст. 13;

6) особи, стосовно яких обрано запобіжний захід у вигляді тримання під вартою, - на правові послуги, передбачені пп. 1 і 3 ст. 13;

7) особи, у кримінальних провадженнях стосовно яких відповідно до положень КПКУ захисник залучається слідчим, прокурором, слідчим суддею чи судом для здійснення захисту за призначенням або проведення окремої процесуальної дії, а також особи, засуджені до покарання у вигляді позбавлення волі, тримання в дисциплінарному батальйоні військовослужбовців або обмеження волі, - на всі види правових послуг, передбачених ст. 13;

8) особи, на яких поширюється дія Закону України «Про біженців та осіб, які потребують додаткового або тимчасового захисту», - на 
всі види правових послуг, передбачених ст. 13, 3 моменту подання особою заяви про визнання біженцем або особою, яка потребує додаткового захисту в Україні, до прийняття остаточного рішення за заявою, а також іноземці та особи без громадянства, затримані 3 метою ідентифікації та забезпечення примусового видворення, 3 моменту затримання;

9) ветерани війни та особи, на яких поширюється дія Закону України «Про статус ветеранів війни, гарантії їх соціального захисту», особи, які мають особливі заслуги та особливі трудові заслуги перед Батьківщиною, особи, які належать до числа жертв нацистських переслідувань, - на всі види правових послуг, передбачених ст. 13;

91) особи, які перебувають під юрисдикцією України і звернулися для отримання статусу особи, на яку поширюється дія Закону України «Про статус ветеранів війни, гарантії їх соціального захисту», - на правові послуги, передбачені пп. 2 і 3 ст. 13, - до моменту прийняття рішення про надання такого статусу;

10) особи, щодо яких суд розглядає справу про обмеження цивільної дієздатності фізичної особи, визнання фізичної особи недієздатною та поновлення цивільної дієздатності фізичної особи, - на правові послуги, передбачені пп. 2 і 3 ст. 13, упродовж розгляду справи в суді;

11) особи, щодо яких суд розглядає справу про надання психіатричної допомоги в примусовому порядку, - на правові послуги, передбачені пп. 2 і 3 ст. 13, упродовж розгляду справи в суді;

12) особи, реабілітовані відповідно до законодавства України, - на правові послуги, передбачені пп. 2 і 3 ст. 13, стосовно питань, пов'язаних з реабілітацією;

13) особи, які постраждали від домашнього насильства або насильства за ознакою статі, - на всі види правових послуг, передбачених ст. 13;

14) громадяни держав, з якими Україна уклала відповідні міжнародні договори про правову допомогу, згода на обов'язковість яких надана Верховною Радою України, а також іноземці та особи без громадянства відповідно до міжнародних договорів, учасником яких $\epsilon$ Україна, якщо такі договори зобов'язують держав-учасниць надавати певним категоріям осіб безоплатну правову допомогу (ст. 14).

Суб'єктами надання безоплатної вторинної правової допомоги є:

1) центри з надання безоплатної вторинної правової допомоги; 
2) адвокати, включені до Реєстру адвокатів, які надають безоплатну вторинну правову допомогу (ст. 15).

Звернення про надання цих послуг, відповідно до ст. 18, подаються особами, які досягли повноліття, до Центру з надання безоплатної вторинної правової допомоги або до територіального органу юстиції за місцем фактичного проживання таких осіб незалежно від реєстрації місця проживання чи місця перебування особи. Звернення, що стосуються дітей, подаються їх законними представниками за місцем фактичного проживання дитини або іiі законних представників незалежно від реєстрації місця проживання чи місця перебування особи, а пов'язані з особами, визнаними судом недієздатними, або дієздатність яких обмежена судом, подаються їх опікунами або піклувальниками за місцем фактичного проживання таких осіб або їх опікунів чи піклувальників незалежно від реєстрації місця проживання чи місця перебування особи.

Разом із зверненням особа або законний представник особи повинні подати документи, що підтверджують належність особи або осіб, стосовно яких звертається законний представник, до однієї з вразливих категорій осіб, перерахованих вище.

Центр 3 надання безоплатної вторинної правової допомоги (надалі - Центр) зобов'язаний упродовж 10 днів 3 дня надходження звернення прийняти рішення щодо надання такої допомоги. У разі подання звернення до територіального органу юстиції, він зобов'язаний упродовж 3 днів 3 дня подання звернення надіслати його до Центру, діяльність якого поширюється на територію відповідної адміністративно-територіальної одиниці. Центр же зобов'язаний у 7-денний строк 3 дня отримання звернення особи прийняти рішення щодо надання допомоги. Якщо особа належить до однієї з категорій осіб, визначених ст. 14, Центр приймає рішення про надання безоплатної вторинної правової допомоги і письмово повідомляє про це

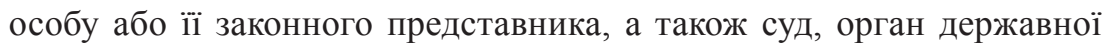
влади, орган місцевого самоврядування, в яких здійснюватиметься представництво інтересів особи.

У разі відсутності підстав для отримання зазначеної допомоги Центр приймає рішення про відмову в наданні такої допомоги і надсилає копію цього рішення особі, яка звернулася про надання допомоги, 
3 одночасним роз'ясненням порядку оскарження рішення про відмову в наданні безоплатної вторинної правової допомоги.

У випадку звернення осіб, зазначених у пп. 3-6 ст. 14, про надання безоплатної вторинної правової допомоги або надходження інформації про затриманих осіб від близьких родичів та членів їхніх сімей, перелік яких зазначено КПКУ, Центр зобов'язаний прийняти рішення про надання такої допомоги з моменту затримання особи.

При отриманні постанови слідчого, прокурора, ухвали слідчого судді, суду про залучення захисника для здійснення захисту за призначенням або проведення окремої процесуальної дії Центр зобов'язаний негайно призначити захисника (ст. 19).

Після прийняття рішення про надання безоплатної вторинної правової допомоги Центр призначає адвоката, який надає таку допомогу на постійній основі за контрактом, або ж уповноважує свого працівника (ст. 21).

\section{4. Висновки}

Результати здійсненого дослідження дозволяють зробити такі висновки:

1. Правові потреби - це потреби людей у якісному й ефективному позитивно-правовому регулюванні, а також в юридичній допомозі.

Їх специфіка полягає у необхідності існування та використання суб'єктом певних державно-юридичних явищ як засобів, котрі формують можливість задоволення його біологічних і соціальних потреб та інтересів.

2. Правові потреби можна розподілити на певні різновиди за загальними критеріями класифікації будь-яких людських потреб, а крім того ще й за критеріями, притаманними саме класифікації правових потреб. До загальних критеріїв належить розмежування за суб'єктом (носієм); сферами людської діяльності; тривалістю; рівнем (ступенем) задоволення. До специфічних критеріїв відносять: за юридично-галузевою ознакою, за юридичним статусом індивідуального носія, за суб'єктом задоволення правових потреб, залежно від безпосередньої участі суб'єкта-носія цих потреб у їх задоволенні. Потреби в якісному й ефективному правовому регулюванні та в юридичній допомозі як різновиди правових потреб можуть бути конкретизовані та диферен- 
ційовані також за додатковими критеріями на: потребу у визнанні юридичної правосуб'єктності (потребу у визнанні правоздатності та дієздатності), потребу в юридичних нормах відповідно до значущості НПА, потребу у суб'єктивних юридичних правах, потребу в юридичних фактах, потребу у законності, потребу у правопорядку, потребу у правовій допомозі.

Як і будь-яка класифікація, наведена класифікація виявляє особливості різноманітних груп правових потреб. Ці особливості мають враховуватися при конструюванні юридичних інструментів задоволення правових потреб та використанні таких засобів.

\section{Список літератури:}

1. Гегель Г.В.Ф. Сочинения: в 14 т. М-Л. : Госиздат, 1935. Т. 8: Философия. $470 \mathrm{c}$.

2. Рабінович П.М. Універсальна теорія права як загальна концептуальна основа теорій національного і міжнародного права (до проблеми формування). Публічне право. 2017. № 3. С. 18-23.

3. Рабінович П. М. Основи загальної теорії права та держави : навч. посібник. 10-е вид., доп. Львів : Край, 2008. 224 с.

4. Баринов Н.А. Имущественные потребности и гражданское право. Саратов : СГУ, 1987.

5. Теорія держави і права. Підручник. Практикум. Тести : підручник. Київ : Юрінком Інтер, 2015. 584 с.

6. Афанасьев В.С. Обеспечение законности: вопросы теории и практики : автореф. дисс. ... д-ра юрид. наук : 12.00.01. Москва, 1993. 41 с.

7. Колодій А.М. Права людини і громадянина в Україні : навч. посіб. Київ : Юрінком Інтер, 2003. 336 с.

8. Скакун О.Ф. Теорія держави і права: підручник. Харків : Консум, 2001. $656 \mathrm{c}$.

9. Пісов М.П. Вплив міжнародного правопорядку на національний правопорядок України. Науковий вісник Херсонського державного університету. 2015. Випуск 5. Том 1. С. 39-42.

10. Про адвокатуру та адвокатську діяльність: Закон України від 05.07.2012 p. № 5076-VI. Відомості Верховної Ради України. 2013. № 27. Ст. 282.

11. Про безоплатну правову допомогу : Закон України від 02.06.2011 p. № 3460-VI, в редакції від 02.10.2018 р. № 2581-VIII. Відомості Верховної Ради Украӥни. 2011. № 51. Ст. 577.

\section{References:}

1. Hehel', H.V.F. (1935). Sochynenyia [v 14 t] [Works: [in 14 t]]. Moskov, Leningrad: Hosyzdat. T. 8. Fylosofyia ystoryy, 470 p. (in Russian) 
2. Rabinovych, P.M. (2017). Universal'na teoriia prava iak zahal'na kontseptual'na osnova teorij natsional'noho i mizhnarodnoho prava (do problemy formuvannia). Publichne pravo, no 3, pp. 18-23.

3. Rabinovych, P.M. (2008). Osnovy zahal'noi teorii prava ta derzhavy [Fundamentals of general theory of law and state tutorial]. L'viv: Kraj, 224 p. (in Ukrainian)

4. Barinov N.A. (1987). Imushhestvennye potrebnosti i grazhdanskoe parvo [Property needs and civil law]. Saratov: SGU. (in Russian)

5. Yurinkom Inter (2015). Teoriia derzhavy i prava. Pidruchnyk. Praktykum. Testy: pidruchnyk [The theory of state and la]. Kyiv: Yurinkom Inter, 584 p. (in Ukrainian)

6. Afanas'ev V.S. (1993). Obespechenie zakonnosti: voprosy teorii i praktiki [Law enforcement: theory and practice]. Moscow, $41 \mathrm{p}$.

7. Kolodij A.M. (2003). Prava liudyny i hromadianyna v Ukraini: navch. posib. [Human and citizen rights in Ukraine: textbook]. Kyiv: Yurinkom Inter, 336 p. (in Ukrainian)

8. Skakun O.F. (2001) Teoriia derzhavy i prava: pidruchnyk [The theory of state and law: a textbook]. Kharkiv: Konsum, 656 p. (in Ukrainian)

9. Pisov M.P. (2015) Vplyv mizhnarodnoho pravoporiadku na natsional'nyj pravoporiadok Ukrainy [Influence of international law on the national law of Ukraine]. Naukovyj visnyk Khersons'koho derzhavnoho universytetu, vol. 5(1), pp. 39-42.

10. Zakon Ukrainy 'Pro advokaturu ta advokats'ku diial'nist"vid 05.07.2012 r. № 5076-VI. URL: https://zakon.rada.gov.ua/laws/show/5076-17

11. Zakon Ukrainy 'Pro bezoplatnu pravovu dopomohu' vid 02.06.2011 r. № 3460-VI. URL: https://zakon.rada.gov.ua/laws/show/3460-17 